CONTRACTUAL NEGOTIATION BETWEEN PETROVIETNAM GAS AND SOLAR TURBINES INTERNATIONAL COMPANY

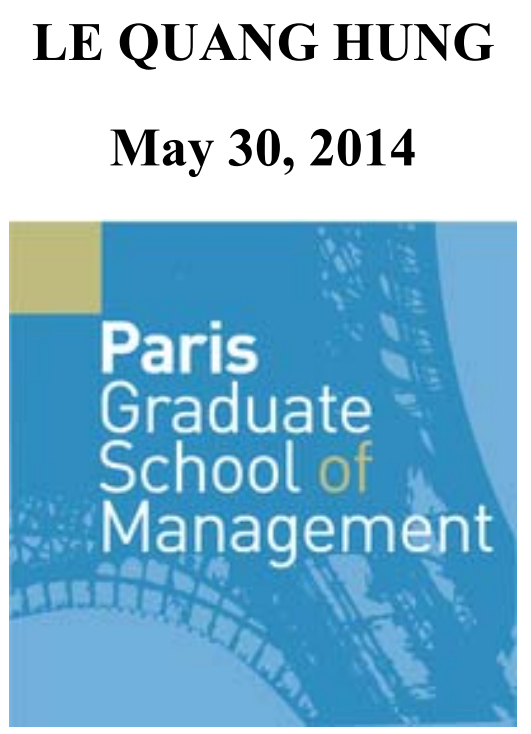

PARIS GRADUATE SCHOOL OF MANAGEMENT 


\section{INDIVIDUAL ASSIGNMENT}

Subject: Intercultural Management

EMBA IEI03

Student's name $\quad$ : LE QUANG HUNG

ID $\quad$ : VN 1001619

Date of completion : $: 30 / 05 / 2014$

Topic :

THE IMPACT OF G. HOFSTEDE'S FIVE CULTURAL DIMENSIONS ON INTERNATIONAL BUSINESS NEGOTIATION IN VIETNAM

CASE STUDY: CONTRACTUAL NEGOTIATION BETWEEN PETROVIETNAM GAS AND SOLAR TURBINES INTERNATIONAL COMPANY 


\section{Table of Contents}

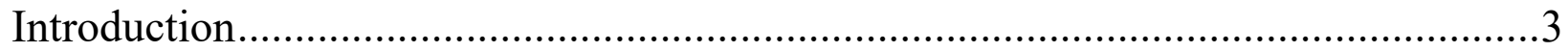

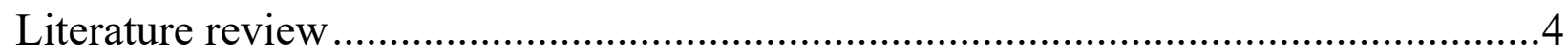

Discussion .........................................................................................

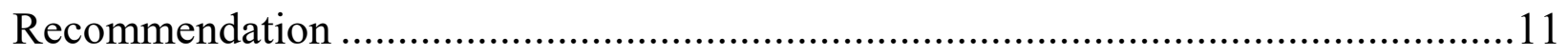

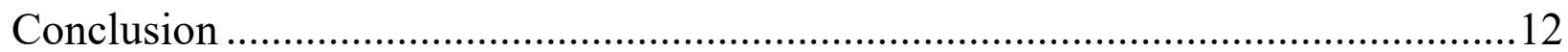

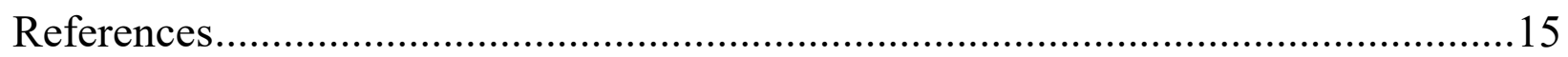




\section{Introduction}

Cultural dimensions constitute the broadest influence on the international business. The international business representatives from different countries when preparing for a business Partnership or the transactions often are analyzing traditions, differences, and properties of other countries. Businesses in order to facilitate business process are trying to adjust to the peculiarities of the other party. In order to achieve this can be analyzed cultural dimensions which can convey the essential incompatibilities between the parties. Analyzing incompatibilities between different cultures there can be used the analysis of Hofstede's cultural dimensions. This can be very useful in the design of international business negotiation processes because it can convey the differences between the different cultural dimensions among the negotiating parties.

This paper explores the impact of five cultural dimensions on International business negotiation in Vietnam, especially business negotiation between Vietnamese and American company. Recently, American companies have become very popular in Vietnam domestic market and played important role in Vietnam's growth. For example, since the US-Vietnam Bilateral Trade Agreement signed 2001, bilateral trade has increased from \$2.9 billion in 2002 to $\$ 24.87$ billion in 2012 . U.S. exports to Vietnam grew by nearly 7.0 percent to $\$ 4.6$ billion in 2012.

In specific case, in November, 2012, a Vietnamese company - Petrovietnam Gas joint stock company (PVGAS) had decided to purchase PM3 Gas Compressor package from Solar Turbines International Company (Solar) - an American company in Delaware, USA and having its registered office at 2200 Pacific Highway, San Diego, CA 92101, USA. The PM3 Gas compressor set package is important part of Gas processing Plant project, located in Camau provine. In order to meet the project's schedule, Solar and Petrovietnam Gas staff had to sign the contract in a short time. However, in the first contract, both parties had spent almost 1 month and nearly 20 negotiation meetings to solve conflicts in negotiation. Fortunately, in the second deal, both parties spent only 5 meetings to get mutual benefit and signed the contact successfully. 


\section{Literature review}

Culture is a set of beliefs and values (Javidan and House, 2001). Hosted By (1991) write that culture is the collective programming of thinking that distinguishes members of one group from the other in terms of values forms, beliefs, assumptions, expectations, perceptions and behavior. Cultural values are desired practice and cultural practice of people, show people's perception of everything what is being done in their countries (House etal, 2002). These cultural conceptions severely affect business culture, and if these cultural differences are not identified, it can lead not only PVGAS but also other international companies experiencing culture shock when dealing with foreign customers, especially in contractual negotiation. Cultural shock undermined time management effectiveness when PVGAS and Solar negotiated the PM3 contract. So we can minimize the impact of culture shock by reviewing different cultural dimension presented by G. Hofstede between Vietnam and United state of America.

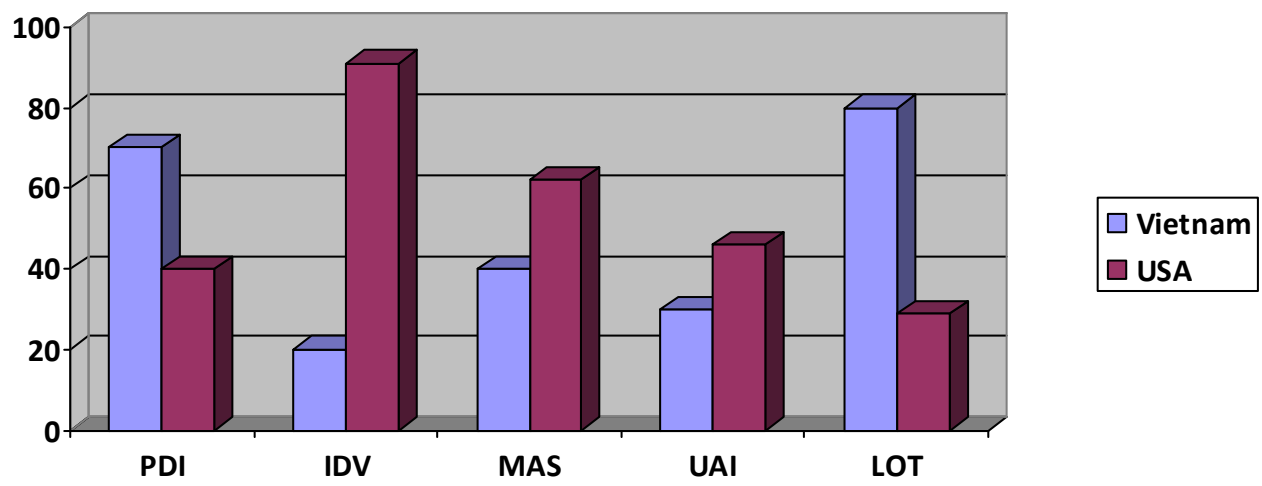

Figure 1: Comparison of value orientations: United States versus Vietnam (ITIM International, 2003)

\section{Cultural competence in Vietnam}

- Vietnam scores high on Power distance Index (score of 70) which means that people accept a hierarchical order in which everybody has a place and which needs no further 
justification. Hierarchy in an organization is seen as reflecting inherent inequalities, centralization is popular, subordinates expect to be told what to do and the ideal boss is a benevolent autocrat. Challenges to the leadership are not well-received (Hofstede, 2001). In Vietnam employees view their organizations as families, and bosses are expected to take care of their employees financially and physically (Adler \& Gundersen, 2008; ITIM International, 2003).

- Vietnam, with an individualism score of 20 is a collectivistic society. Vietnam is considered a fairly collectivist culture. Because of their Confucian roots, Vietnamese culture is strongly orientated around family and community. Family comes before oneself. Therefore, they value the collective whole rather than the individual. To bring pride to one's family is the ultimate goal (Hofstede, 2001).

- Vietnam scores 40 on Masculinity and is thus considered a feminine society. In feminine countries the focus is on "working in order to live", managers strive for consensus, people value equality, solidarity and quality in their working lives. Conflicts are resolved by compromise and negotiation. Incentives such as free time and flexibility are favored. Focus is on well-being, status is not shown. An effective manager is a supportive one, and decision making is achieved through involvement (Hofstede, 2001).

- Vietnam scores 30 on uncertainty avoidance index (UAI) and thus has a low preference for avoiding uncertainty. Low UAI societies maintain a more relaxed attitude in which practice counts more than principles and deviance from the norm is more easily tolerated. In societies exhibiting low UAI, people believe there should be no more rules than are necessary and if they are ambiguous or do not work they should be abandoned or changed. Schedules are flexible, hard work is undertaken when necessary but not for its own sake, precision and punctuality do not come naturally, innovation is not seen as threatening. 
- Vietnam is high on long-term orientation (80). They are hard-working and respect their superiors. They value the relationships they build not the results they get right away. ${ }^{1}$

\section{Cultural competence in America}

- America scores 40 on Power distance index is medium. It means that in America, people are more equal than Vietnam. As a result, inside an organization, the distance between boss and staff is not too far. Staffs are expected to do the best they can. Normally, American staff can make decision without approval from managers because they are authorized. Many American assessment systems are based on precise target setting, by which American employees can show how well a job they did.

- America score 91 on Individualism means every American is unique, America is Individualism society. It has to do with whether people's self-image is defined in terms of "I" or "We". In Individualist societies people are only supposed to look after themselves and their direct family.

The fairly low score on Power Distance (40) in combination with of the the most individualistic (91) cultures in the world reflects itself in the following:

- The American premise of "liberty and justice for all." This is evidenced by an explicit emphasis on equal rights in all aspects of American society and government.

- Within American organisations, hierarchy is established for convenience, superiors are accessible and managers rely on individual employees and teams for their expertise.

- Both managers and employees expect to be consulted and information is shared frequently. At the same time, communication is informal, direct and participative to a degree.

- The society is loosely-knit in which the expectation is that people look after themselves and their immediate families only and should not rely (too much) on authorities for support.

\footnotetext{
${ }^{1}$ http://academic.depauw.edu/mkfinney_web/teaching/Com227/ culturalPortfolios/VIETNAM/VIETNAM/typologies.html
} 
- There is also a high degree of geographical mobility in the United States. Americans are the best joiners in the world; however it is often difficult, especially among men, to develop deep friendships.

- Americans are accustomed to doing business or interacting with people they don't know well. Consequently, Americans are not shy about approaching their prospective counterparts in order to obtain or seek information. In the business world, employees are expected to be self-reliant and display initiative. Also, within the exchange-based world of work we see that hiring, promotion and decisions are based on merit or evidence of what one has done or can do. ${ }^{2}$

- The score of the US on Masculinity is high at 62, and this can be seen in the typical American behavioral patterns. This can be explained by the the combination of a high Masculinity drive together with the most individualistic drive in the world. In other words, Americans, so to speak, all show their masculine drive individually

- The US scores below average, with a low score of 46, on the Uncertainty Avoidance dimension. As a consequence, the perceived context in which Americans find themselves will impact their behaviour more than if the culture would have either scored higher or lower. Thus, this cultural pattern reflects itself as follows:

- The low ranking of Long-term Orientation reflects a freedom in the culture from long-term traditional commitments, which allows greater flexibility and the freedom to react quickly to new opportunities. Americans are the best joiners in the world and focused on the presence and past and considered them more important than future.

\section{Discussion}

\section{Cultural Impact on Negotiations}

\footnotetext{
${ }^{2}$ http://geert-hofstede.com/united-states.html (last visited 28th May, 2014)
} 
Various misunderstandings in negotiations may occur among the same culture of the negotiating parties also; in the case of negotiation between different cultures it is necessary to know the basic elements of the incompatibility of the negotiating parties. In the international business communication can take place misperceptions of symbols of different cultures. As the negotiation process without communication is impossible, therefore, impact of culture on the international business negotiations is significant.

Culture is an important variable influencing the international negotiations and performance. Values and norms which are included in culture, can affect the negotiation either stronger or weaker. Some authors argues that culture, accountability and group membership can determine not only approach to relationships in the negotiations and after (negotiated rates), but also likely to influence and the outcome of negotiations.

Intercultural negotiation is a complex process of interaction between two or more companies, organizations, or their compounds, originating from a variety of nations and seeks definition of their mutual dependence. Negotiators tactics are influenced by several key factors: the negotiators trust, possession of alternatives, conflict background, time available, social sustainability, ethics, etiquette, political affiliation, and cultural distance. Negotiating partners, conflicts often arise because of the differences in perception, preferences, behavioral styles and objectives of the transaction to fail is to risk for each country of opportunistic behavior and private initiatives. Culture and expectations between cultures affects all business transactions, culture is a factor covering business ethics (Pitta, 1999). It is noted (Pitta. 1999), the corporate culture is based on the time-tested and traditional practices prevailing business practices and way of thinking for a long period, which lasted for hundreds or even thousands of years, during which, and has formed a business culture in the country. Christopher and cousin (2005) found that cultural values creates a negotiating rate differentials, so it is useful to find and to understand the relationship between the other country's culture and negotiation strategies. Negotiator behavior is perceived depends on the other negotiator's focus on the other side of behavior, 
ability to learn, to understand and to conduct the evaluation. Therefore, if only one of the circuit elements and error occurs, you can expect failure or misunderstanding.

In some cultures, bargaining is acceptable and even required. In other cultures, bargaining might be considered impolite or even insulting. Different cultures and different religions can lead to dramatically different reactions for the same behavior.

When negotiating at international level, it is important to collect and organize information not only on the other side of the negotiations, but also on the context of the negotiations. It may be, effect legal changes, political processes, and many others important factors in a particular bargaining situation of other entities that have an influence. In the next section will be examined the context of intercultural of negotiations.

Solar Turbines International Company located in San Diego, USA, is subsidiary of Caterpillar Tractor Corporation - one of biggest corporation in Oil and Gas equipment manufacturer over the world. In 2011, Solar won bidding to supply PM3 Gas compressor to Petro Vietnam Gas. PM3 Gas compressor was a first contract between Solar and PVGAS. Therefore, realize PVGAS is very important customer in order to expand market share in Vietnam, Solar agreed to sell PM3 with much cheaper price than competitor. Solar intended to sell the second Gas compressor to PVGAS in next phase of the project, but with higher price than the first one. This was hard challenge to Solar negotiators and they were successful. In order to overcome this situation, Solar negotiators clarified some taboos and cultural shock of Vietnam as the following:

- Vietnamese culture has to a great extent been influenced by "Confucianism" which is a philosophical and ethical system that guides human relationships ( $\mathrm{Lu}, 2009)$. That is why Vietnam is collectivistic society. A common Vietnamese perception was that close personal relationships could promote more opportunities in every aspects of life. Relationship is important for the development of business everywhere, but it is color in East Asian cultural setting is quite different from the West. Relationship in Vietnam 
(quan he) refer to many social aspects between individuals, and is rarely limited within the scope of professional works.

- Before Vietnamese do business, the first things they look at are trust and relationships (C. Nguyen, personal communication, November 9, 2007). A major challenge for American companies like Solar entering the Vietnamese market is that they will have to develop relationships and a network before they can get anywhere.

- Because of high power distance so only high level person in Vietnam can make important decision. High level could be understood in state-owned company is members of government. In practice, almost biggest companies in Vietnam are state owned companies. In many other situations, act of seeking business opportunities is performed, based on assumptions that benevolence from the government is an essential prerequisite. The private entrepreneur has to do so to their vested interest because of the tendency of the government acting like a parent in the society, in the name of retaining orderly society and stability.

- Public companies (PetroVietnam - a mother company of PVGAS, FPT, Vinashin ...) prefer to copy strategies from one another. Many big names on the local bourse have subsidiaries/associated companies in securities, real estates, communications, and banking industries.

- Vietnamese companies usually are not happy with the time-consuming administrative process, directly related to their operations, most infamous ones including complicated taxes, overwhelming business setup procedures, and investment appraisal/approval steps, etc. However, entrepreneurs choose to buy the 'services' when facing situations like these both to save costs and keep good relations with concerned authorities as both are equally important.

- "How much is your discount" is the first Vietnamese concern when negotiate. Because of low uncertainty avoidance, Vietnamese do not care much about quality of product in the future. When they finish purchasing one goods or equipment, they will report to higher level how much they saved for government and may they will be promoted. 
- In the collectivist Vietnamese society, "good face" was a combination of dignity, selfrespect, prestige and high social standing, as perceived by other (Chen, 1995). Vietnamese always need for protecting "face" of themselves in front of others. Remember this, never make Vietnamese lose face, especially if this was done in the presence of others by criticizing them.

\section{Recommendation}

Through the literature above it can be noted that cultural differences between Vietnamese and American are big challenges that negotiators have to overcome. Hence some of the key recommendations provided for American negotiator doing business in Vietnam by summary what Solar negotiators did in the second deal. These are the following:

- The first thing American negotiators should do when doing business in Vietnam is hire mediators (should be local people) to convey cultural differences between two parties. In fact, Solar hired Toanthang International Company - a 100\% Vietnamese company to joint every negotiation meeting.

- Solar negotiator always came earlier 15 minutes from the time of beginning of the meeting for visiting management Board of the project and saying salutation because they deeply realize that only the highest level of management board of the project can decide to buy their product.

- Besides doing business, Solar negotiators with their mediators Toanthang company focused on developing the relationships both Petrovietnam - a mother company of PVGAS and PVGAS management board. They invited those people joining Golf party in Thailand, Vungtau, Danang and pay all for the trips.

- In beginning of the meetings, Solar negotiators always talk about the family, education of Vietnamese members. Because they know that with Vietnamese in collectivist society, family is very important with them.

- Solar knew that PVGAS is public company so they prefer to copy strategies from one another, so in the past, Solar tried to join some projects as sub-contractors of other 
companies to supply auxiliary equipment in Oil and Gas field like Vietsopetro, Petrovietnam oil. This was way solar build the trust of PVGAS management board.

- With the time-consuming administrative process like translating the contract, Solar knew PVGAS did like to read the contract in English, so they asked mediators to translate from English into Vietnamese in some difficult and important Terms and Conditions of the contract.

- Vietnamese are deeply influenced by Confucian. They prefer to communicate indirectly. In the meeting, they never say "yes" or "no" directly with important issues. They always talk "the problem is not too big and I will report to my boss and tell you the result later". So American negotiators have got to do more digging and never give up.

- Because of low uncertainty avoidance, Vietnamese always want to have discount in every contract and did not care much about the quality of product in future. Solar chosen to offer a higher price than actual and then give from 1 to $5 \%$ discount.

- Vietnamese company always buy product with cheapest price. To won the bidding process, Solar offered the cheapest price in comparison with competitors. The reason is they shortened warranty time of the product from 24 months to 12 months.

- Finally, Solar working across cultural, Solar focus on training employees in project management, time keeping and teach them cultural differences between customers. Because of International company, Solar hired employees come from many countries and ask them deal the contract with the same nationality negotiator in opposite site.

\section{Conclusion}

The scientific literature does not sufficiently investigated the effects of the process of crosscultural negotiating to the final results of negotiations. Intercultural negotiation plays a significant role in the cultural dimension. They may have a negative influence on negotiating communication understanding differently various cultural values, symbols, 
patterns and so on. It is necessary to foresee these elements in the preparation of negotiating strategies in the negotiations at transnational level.

There are necessary to provide for potential cross-cultural incompatibilities in the intercultural negotiations, previously getting acquainted with different cultures and to foresee measures to prevent or solve them. In order to prepare for negotiations it is necessary also to develop an effective negotiating team whose analytical work and capacities contribute to the achievement the highest outcome of the negotiations. This is particularly important in the context of preparing for intercultural negotiations, which require an understanding of another culture, another language, possession of legal knowledge, knowledge of the negotiation context and so on. In forming the strategy of negotiations it is needed to get acquainted with the negotiating context. When planning the international business talks, preparation is usually more complex than between the subjects of the same country or regional negotiations. The analysis of the global scientific literature revealed a lack of research on the impact of cross-cultural context of the negotiations to the negotiation process and outcome

\section{References}

Aisa Society, (2012a) Confucianism.. Available from http://asiasociety.org/countries/ religions-philosophies/confucianism (Last visited 26th May, 2014)

Baker Ted, Gedajlovic Eric, \& Lubatkin Michael. (2005). "A Framework for Comparing Entrepreneurship Processes Across Nations". Journal of International Business Studies, Vol. 36, No. 5, pp. 492-504.

Farber André, Nguyen Van Nam, \& Quan Hoang Vuong. (2006). "Policy Impacts on Vietnam Stock Market: A Case of Anomalies and Disequilibria 2000-2006". Working Papers CEB, No. 06-005.RS, SBS-EM, Université Libre de Bruxelles, Belgium. 
Claire Andre and Manuel Velasquez, "Creating the Good Society "(online). Available from http://www.scu.edu/ethics/publications/iie/v5n1/homepage.html (last visited 29th May, 2014).

Hooper, Christopher and Pesantez, Maria (2005), "Cross-Cultural Communication and Negotiation, International Business Journal.

Sungmin Ryu and Chul Woo Moon (2009), "Long term orientation as a determinant of relationship quality between channels member", International Business and Research Journal, Vol 8, No 11.

Vuong Quan Hoang, \& Tran Tri Dung. (2009), "The Cultural Dimensions of the Vietnamese Private Entrepreneurship". The IUP Journal of Entrepreneurship and Development, Vol 6, No. 3, pp. 54-78. (Accessed: 27th May, 2014)

Vuong Quan Hoang. (1997a). “A Question of Leverage”. Vietnam Investment Review, p. 13 (24-30 March 1997).

Vuong Quan Hoang. (1997b). “The Leasing Alternative”. Vietnam Business Journal, Vol 5, No 3, p. 26.

Vuong Quan Hoang. (2004). “The Vietnam's Transition Economy and Its Fledgling Financial Markets: 1986-2003”. Working Papers CEB, No. WP-CEB 04-032, Solvay Business School, Université Libre de Bruxelles (Brussels, January 2004). 